\title{
Stock market development and economic growth: Empirical evidence for emerging market economies
}

\author{
Abiy Hailemariam, Chi Guotai* \\ School of Business Management, Dalian University of Technology, Dalian, 116024, China \\ Email address: \\ abiy_hmariam@yahoo.com (A. Hailemariam),chigt@dlut.edu.cn (Chi Guotai),chigt163@163.com (Chi Guotai)
}

To cite this article:

Abiy Hailemariam, Chi Guotai. Stock Market Development and Economic Growth: Empirical Evidence for Emerging Market Economies. International Journal of Economics, Finance and Management Sciences. Vol. 2, No. 2, 2014, pp. 171-181.

doi: $10.11648 /$ j.ijefm.20140202.19

\begin{abstract}
Contemporary economies of developing countries are changing due to rapid changes in the world economy. The economies of emerging market countries are witnessing changes in the composition of capital flows because world stock markets are expanding rapidly. Foreign direct investment and stock market boom are the indicators of the changing world economic order. The objective of this study is to examine the relationship between stock market development and economic Growth. Empirically, based on the data for 17 emerging market and 10 developed market economies during the 12 years' period, from 2000 - 2011 using the generalized method of momentum (GMM) for dynamic panel data. To control for the country specific effect, the model is further estimated for the developed and emerging member economies. The key findings of the study reveal that there exists statistically significant relationship between stock market development and economic growth both directly, as well as indirectly by boosting investment behavior. The results also indicate robustly that stock market development is an important wheel for economic growth.
\end{abstract}

Keywords: Stock Market Development, Economic Growth, Dynamic Panel, Emerging Market and Developed Market Economies

\section{Introduction}

Stock markets attract the attention of economists, finance experts and policy makers because of the perceived benefits it provides for the real economy. It is the fulcrum of capital market activities and is often cited as a barometer of business direction. It also serves as an important instrument in the mobilization and allocation of savings among competing users and uses, which are critical to the growth and efficiency of an economy. In other words, the stock market is a critical cog in the wheel of the economy that facilitates the transfer of funds for economic growth. For sustainable economic growth and development, funds must be effectively mobilized and allocated to enable businesses and economies to harness their human, material, and management resources for optimal output.

Another important aspect through which stock market development may influence economic growth is risk diversification. Obstfeld (1994) suggested that international risk sharing through internationally integrated stock markets improves the allocation of resources and accelerates the process of economic growth. During liquidity shocks, investors can sell their shares to another agent. Stock markets may also promote growth by increasing the proportion of resources allocated to firms. Through the diversification of productivity risk, even risk-averse investors can invest in firms. Portfolio diversification, through the stock market, may have an additional growth effect by encouraging specialization of production.

Furthermore, An organized and managed stock market stimulate investment opportunities by recognizing and financing productive projects that lead to economic activity, mobilize domestic savings, allocate capital proficiency, help to diversify risks, and facilitate exchange of goods and services (Mishkin, 2001; and Caporale et al., 2004). Undoubtedly, stock markets are expected to increase economic growth by increasing the liquidity of financial assets, make global and domestic risk diversification possible, promote wiser investment decisions, and influence corporate governance, i.e., solving institutional problems by increasing shareholders' interest/value.

In addition to above, stock markets are best indicator to 
forecast future economic activity and describe actual casual affect between future economic growth and stock prices. A more difficult question arises with respect to whether the forward-looking nature of stock prices could be driving apparent causality between stock markets and growth. Current stock market prices should represent the present discounted value of future profits. In an efficient equity market, future growth rates will, therefore, be reflected in initial prices. This argues for using turnover (sales over market capitalization) as the primary measure of development, thereby purging the spurious causality effect because higher prices in anticipation of greater growth would affect both the numerator and the denominator of the ratio.

Finally, Stock markets are places where corporate control mechanism is at work. As the economic performance of corporations is reflected in, and measured by, stock prices, corporate managers would try hard to minimize agency problems and to maximize shareholders wealth. In a market economy the link between corporate profits and economic growth is quite obvious. Moreover Stock exchanges are expected to increase the amount of savings channeled to corporate sector. Some evidence can be found in the work of Greenwood \& Jovanovich (1990).

In fact the relationship between stock market and the real economy growth across country is yet a moot point and also scantly researched or examined. The relationship between financial development (represented by only banking sector development) and the real economy and it thus ignored the role of stock markets in the economic growth and development process across a country. Examination of the role of stock markets in economic growth is more relevant for emerging and developed market economies because there has been tremendous increase in stock market activities in the last two decades.

Our study examine the role of stock market development and economic growth Using the Generalized method of moments (GMM) for dynamic models of panel data for emerging market and developed market economies from 2000-2011, we find robust evidence for this relationship. Stock market Development has significant causal effect on economic growth.

Besides, we include several measures of stock market development (as opposed to a single composite measure used by Levine and Zevros 1998). This more disaggregated approach is also recommended by Demirguc Kunt and Levine (1996). In what follows, Section 2 discusses the theoretical literature review; Section 3 discusses the empirical approach, including (3.1) a discussion of the measures of the stock market development and economic growth, and (3.2) econometric methodology of the study and data source; Section 4 presents the panel regression result of the model; and Section 5 presents concluding remarks and summary.

\section{Literature Review}

There is a substantial amount of literature that tries to explore the relationship between financial development and economic growth. These studies largely confirm that stock market development have strong positive effect on growth (Levine and Zervos, 1998; Bekaert et al., 2001; Beck and Levine, 2004). In the light of the rapid development in stock markets, more recent studies expand the analysis to examine the linkage between stock market development and economic growth. In addition to the banking sector development, Levine and Zervos (1998) first incorporate stock market development as another potential source of economic growth. The results are consistent with the notion that a well-developed stock market would promote higher growth.

In particular, the measures of financial development such as stock market liquidity are positively correlated with the current and future rates of economic growth. The latest study by Beck and Levine (2004) confirms this finding and further argues that the stock market development is important in enhancing growth. Bekaert et al. (2001) report a similar positive effect of financial development on growth.

The major measures of the stock market (stock market turnover and number of domestic companies) are indeed positively correlated with economic growth. They also find that the stock market liberalization plays a crucial role in facilitating growth. The opening up of the stock market to foreign investors would certainly promote high economic growth especially in countries with a highly educated labor force. Two of the latest studies also emphasize the growing importance of stock market development in accelerating growth. Mauro (2003) posits that countries with well developed stock markets tend to experience higher stock returns, which would possibly accelerate economic growth in the long run. This is especially applicable to the experience of developed countries as they have better financial infrastructures to monitor their stock market operations.

Evidence obtained by Minier (2003) also indicates that the growth enhancing effect may be higher especially in countries with well-developed stock markets. The result further suggests that the substantial growth effect may take some time to appear, particularly for countries with less developed stock markets. While most of the previous studies have confirmed the importance of financial development on growth, later studies attempt to find other possible determinants of economic growth. Edison et al. (2002) first consider capital flow as a potential source of economic growth. Among the five variables measuring financial integration, only the capital inflow and outflow variables show significant positive effects on economic growth.

The substantial growth-enhancing effect of capital flow has also been found by Levine (2000). He argues that capital flow can facilitate high growth through its impact on the stock market and the banking sector respectively. The liberalization of capital flow across countries would increase stock market liquidity, further accelerating economic growth. Equally important, the opening up of the banking sector to foreign investors would create a more competitive atmosphere in the banking sector. This would spur more improvement in domestic banking efficiency, 
thereby boosting economic growth. Despite the strong evidence of a finance-growth relationship, recent literature begins to question the issue of simultaneity bias. While numerous studies find that a high level of financial development would promote economic growth, it is also the case that high growth may in fact boost financial development in stock markets and the banking sector. By and large, more recent studies attempt to address the issue of simultaneity bias.

In particular, two studies find a bi-directional causality effect (Demetriades and Hussein, 1996; Kassimatis and Spyrou, 2001). The results indicate that while financial development would promote economic growth, high economic growth would be equally likely to facilitate stock market and banking sector development. Specifically, economic growth would enhance financial development as high growth countries usually have higher demand for financial services. The result also reveals that the exact pattern of finance-growth causality may vary across countries.

Graff (2002) further explores this issue and provides a more detailed analysis of the causal relationship. He points out that there exist two alternative empirical relationships other than the bi-directional causality relationship found in similar studies. First, there may be no causal relationship between financial development and economic growth. This occurs as economic growth increases at the same rate as that of financial development. Second, financial development may have a negative effect on economic growth as it may result in destabilizing effects such as financial crises.

Moreover, better financial infrastructures would usually induce more investment in higher return projects, possibly leading to high economic growth. This argument is further supported by Deidda and Fattouh (2002). They note that the magnitude of growth effect would increase directly with the level of economic development. Second, another major factor that can affect the finance-growth relationship is the degree of financial liberalization in the stock market and the banking sector Evidence obtained by Kassimatis and Spyrou (2001) indicates that financial development would further boost economic growth in countries with a more liberalized financial market, especially those with a high level of stock market liberalization.

In contrast, countries with highly regulated financial markets controlled by the government would derive lower and even short-term growth effects of stock market development. Given the fact that these stock markets may be poorly managed, the stock market development can actually hinder rather than promote economic growth. Similarly, Demetriades and Hussein (1996) point out that the high level of government control on the banking sector may slow down the progress of financial development and subsequently impede economic growth.

Furthermore, stock markets play an important role in allocation of capital to corporate sector that in turn stimulates real economic activity. Many countries were facing financial constraints particularly developing countries, where bank loans are restricted to some favorable groups of companies and personage investors. This limitation can also reflect constraints in credit markets (Mirakhor \& Villanueva, 1990). Due to stagnant bank's return from lending to specific groups of borrowers, this return does not increase as the interest rate to borrowers rises [Stiglitz \& Weiss, (1981); and Cho, (1986)].

Efficient stock markets provide guidelines as a mean to keep appropriate monetary policy through the issuance and repurchase of government securities in the liquid market, which is an important step towards financial liberalization. Similarly, well organized and active stock markets could modify the pattern of demand for money, and would help create liquidity that eventually enhances economic growth (Caporale et al, 2004) ${ }^{1}$.

In 19th and 20th century, academics such as Bagehot (1873) and Schumpeter (1911) had focused on the constructive assistance of financial sector to economic growth. Though the direction of causality between the higher growth in financial sector and country's economic growth rate was not clear (Robinson, 1952 \& Locus, 1988)4. Recent literature has paid much attention on banking sector reforms because there is a growing and mounting interest about stock market and economic growth nexus. According to Levine (1997) and Bencivenga (1991), more liquid markets can create long-term investment and hence economic growth through lower transaction cost. Likewise, Levine and Zervos (1998) remarked that stock markets liquidity positively predicts aggregate economic growth. Rajan and Zingales (1998) argued that stock market size is correlated to growth of financial dependent firms ${ }^{2}$.

Traditional growth theorists believed that there is no correlation between stock market development and economic growth because of the presence of level effect not the rate effect. Similarly, Singh (1997) contended that stock markets are not necessary institutions for achieving high levels of economic development. Many viewed stock market as a agent that harm economic development due to their susceptibility to market failure, which is often manifest in the volatile nature of stock markets in many developing countries (Singh, 1997; \& Weis, 1999). So, the traditional assessment model of stock prices and the wealth effect provide hypothetical explanation for stock prices to be proceeded as an indicator of output (Comincioli, 1996). According to wealth effect, however, changes in stock prices cause the variation in the real economy.

\footnotetext{
1 Stock prices determined in exchanges and other publicly available information help investors make better investment decisions. Better investment decisions by investors mean better allocation of funds among corporations and, as a result, a higher rate of economic growth. In efficient capital markets prices already reflect all available information, and this reduces the need for expensive and painstaking efforts to obtain additional information (Stiglitz 1994).

${ }^{2}$ First time Gurley and Shaw (1955) efficient financial markets can enhance a borrower's capacity and improve the efficiency of trade.

${ }^{3}$ Bhide (1993) indicates that the volatility of stock market may reduce the ability of the public to supervise on a company's investment efficiency. In addition, the public may increase investment returns by speculating in the stock
} 
Contrary to traditional view, there are evidences that support the hypothesis that there exists long-run correlation between stock market development and economic growth. But in literature the testing of this hypothesis is rare for developing countries. However, Pardy (1992) in his seminal work has argued that in less developed countries capital markets are able to mobilize domestic savings and allocate funds more efficiently. Spears (1991) reported that in the early stages of development, financial intermediation induced economic growth. Similarly, Atje and Jovanic (1993) concluded that stock markets have long-run impacts on economic growth and it was also found that stock markets manipulate economic growth through a number of channels that are liquidity, risk diversifications, acquisition of information about firms, corporate governance and savings mobilization (Levine \& Zervos 1996). Luintel and Khan (1999) examined bi-directional causality between financial development and economic growth.

Levine and Zervos (1998) measured stock markets development along with different magnitude and have suggested a strong statistically significant relationship between initial stock market development and subsequent economic growth. Filer et al. (1999) and Tuncer and Alovsat (2001) examined stock market-growth nexus and exhibited positive casual correlation between stock market development and economic activity. Chen et al (2004) elaborated that the nexus between stock returns and output growth and the rate of stock returns is a leading indicator of output growth.

Paudel (2005) acknowledged that stock markets, due to their liquidity, enable firms to attain much needed capital quickly, hence facilitating capital allocation, investment and growth. Adjasi and Biekpe (2005) found a significant positive impact of stock market development on economic growth in countries classified as upper middle-income economies. Bahadur and Neupane (2006) concluded that stock markets fluctuations predicted the future growth of an economy and causality is found only in real variables. More specifically the causality runs from market capitalization to economic growth with significant feedback. Various studies such as Spears, (1991); Levine and Zervos, (1998); Atje and Jovanovic, (1993); Comincioli, (1996); Filer et al, (1999); Levine and Zervos (1995) and, Demirguc-Kunt (1994) has supported the view stock markets promote economic growth.' With well-functional financial sector or banking sector, stock markets can give a big boost to economic development. Beck \& Levine,(2004).

Stock markets are found making headlines almost daily, be it in print or electronic media. We are always swamped with news on the wild gyrations of the S\&P, CNX Nifty, NASDAQ, the Dow Jones Industrial Average and the like. It is in fact hard to imagine a world without stock markets now. This surge in interest in the role and importance of stock markets in the feature of the last 15-20 years,

market; thus, the stock market development may be unfavorable to the economic growth. especially in the case of Emerging countries.

In the contemporary scenario which can be described by increasing integration of the financial markets and implementation of various stock market reform measures across the world, a study of the stock markets and their relationships with the real economy have assumed significant importance. Furthermore, there is no conclusive evidence suggesting a definite relationship between stock market developments and economic growth among developed and emerging market economies. Most of the earlier empirical studies were preoccupied with bank measures of financial deepening and development and ignored the role of stock market.

Much of the confusion has been removed from literature review as in theoretical framework. Our study utilizes a rich and disaggregated panel data by adopting a dynamic panel approach to examine the relationship between stock market development and economic growth. Specifically, our sample consists of 17 Emerging markets and 10 developed market economies over 12 years (2000-2011). These features have been possible by our use of a rich database, the Emerging Market Database (EMDB) from the International Financial Cooperation (IFC) and world development indicator (WDI) from the World Bank.

\section{Empirical Approach and Methodology}

\subsection{Measurement of Stock Market and Other Variables}

The objective of this study is to examine whether stock market development would promote economic growth among emerging market and developed market economies from the year 2000 up to 2011. First, as mentioned, by being able to draw data from a single data source, we overcome the Consistency and measurement problems that are associated with Levine and Zevros' (1998) use of two different data sources. Second, to maximize the use of information extracted from the data, we use several different measures of stock market development ${ }^{4}$.

The set of variables to measure the stock market development includes Market capitalization, Total Value of Shares Traded, and Turnover ratio. First, the common indicator for the size of stock market is Market capitalization. A larger value of Market Capitalization ratio indicates a large country with a larger stock market. In this regard, a country with a well developed stock market tends to have a larger stock market relative to the size of its economy. Second, the two variables that measure the level of stock market liquidity are Volume Trade and Turnover. Volume Trade is the total value of stock being traded divided by GDP. Since Volume Trade measures the volume

\footnotetext{
${ }^{4}$ Levine and Zevros, use long term average values for a cross section of fortyone countries over the period from 1976 to 1993, following Barro-type crosssectional approach (1991), thus glossing over potentially important country specific variations in the observation.
} 
of stock being traded as a share of total output, it should accurately reflect the stock market liquidity relative to the size of the economy (Levine and Zervos, 1998).

Another stock market liquidity variable is Turnover, which equals the total value of stock being traded divided by the total value of stocks listed on the domestic market. It is important to distinguish between Turnover and Volume Traded as they reflect different aspects of stock market development. Turnover measures the volume of stock trading relative to the size of stock market, whereas Volume Traded measures the volume of stock trading relative to the size of the economy. This would render Turnover a more objective indicator for stock market liquidity than Volume Trade regardless of the size of the economy. A small but liquid stock market would still have a high value of Turnover. Similarly, a large but inactive stock market would have a low value of Turnover (Levine and Zervos, 1998).

Using a variety of measures provides a richer picture of the potential links between stock market development and economic growth than if a single measure is used. In this sub section we describe the various measures of stock market development and other control variables.

\subsubsection{Stock Market Variables}

Market Capitalization Ratio (CAP): This measure equals the value of listed shares divided by GDP. The assumption behind this measure is that overall market size is positively correlated with the ability to mobilize capital and diversify risk on an economy-wide basis.

$$
C A P=\frac{\text { Stock Market } \text { Capitalization }}{\text { Market GDP }} \times 100
$$

Total Value of Shares Traded Ratio (STV): This measure equals total value of shares traded on the stock market exchange divided by GDP. The total value traded ratio measures the organized trading of firm equity as a share of national output and therefore should positively reflect liquidity on an economy-wide basis. The total value traded ratio complements the market capitalization ratio: although a market may be large, there may be little trading.

$$
\text { STV }=\frac{\text { Total value of shares }}{\text { Market GDP }} \times 100
$$

Turnover Ratio (STR): This ratio equals the value of total shares traded divided by market capitalization. Though it is not a direct measure of theoretical definitions of liquidity, high turnover is often used as an indicator of low transaction costs. The turnover ratio complements the market capitalization ratio. A large but inactive market will have a large market capitalization ratio but a small turnover ratio. Turnover also complements the total value traded ratio. While the total value traded ratio captures trading relative to the size of the economy, turnover measures trading relative to the size of the stock market. A small liquid market will have a high turnover ratio but a small total value traded ratio.

$$
S T R=\frac{\text { Total } \text { value of } \text { shares }}{\text { Market capitalization }} \times 100
$$

\subsubsection{Other Macroeconomic Variables}

GDP Growth: Annual percentage growth rate of GDP at market prices based on constant local currency. Aggregates are based on constant 2000 U.S. dollars. GDP is the sum of gross value added by all resident producers in the economy plus any product taxes and minus any subsidies not included in the value of the products. It is calculated without making deductions for depreciation of fabricated assets or for depletion and degradation of natural resources. This measure is from the World Development Indicators (2000) data set.

Foreign Direct Investment $(F D I)$ : Foreign direct investment is used as a control variable since it is presumed that FDI is a determinant of economic growth. Foreign direct investment are the net inflows of investment to acquire a lasting management interest (10 percent or more of voting stock) in an enterprise operating in an economy other than that of the investor. It is the sum of equity capital, reinvestment of earnings, other long-term capital, and short-term capital as shown in the balance of payments. This series shows net inflows (new investment inflows less disinvestment) in the reporting economy from foreign investors, and is divided by GDP.

\subsection{Empirical Approach}

We use a pooled data set of cross-country. A dynamic panel data approach is used that covers for 17 emerging market and 10 developed market countries. This approach allows us to control for country specific effects as well as for one-way or two-way effects. The econometric computer software Eviews 6.0 is used for the estimation of the model that is suited to panel data, deals with static or dynamic regression specifications, controls for unobserved time and country-specific effects, and accounts for some endogeneity in the explanatory variables. As mentioned in the introduction, this system is the GMM developed by Arellano and Bond (1991), and Holtz-Eakin et al. (1989) for dynamic models of panel data.

GMM deals with unobserved time effects through the inclusion of period-specific intercepts. Dealing with unobserved country effects is not so simple given the possibility that the model is dynamic and contains endogenous explanatory variables. Thus, unobserved country effects need to be controlled for by differencing and instrumentation. Likewise, the method relies on instrumentation to control for joint endogeneity. Specifically, it allows relaxing the assumption of strong exogeneity of the explanatory variables by allowing them to be correlated with current and previous realizations of independent disturbance.

\subsubsection{Model}

The model examines the relationship between stock market development and economic growth directly, since 
we focus on growth, the model is in the form of a panel estimate of growth following such works as Islam and lee
(1995).

The model developed in this study is given as follows:

$$
G D P_{i t}=\alpha_{i}+\gamma_{t}+\delta_{1}(C A P)_{i t}+\delta_{2}(S T V)_{i t}+\delta_{3}(S T R)_{i t}+\phi_{1}(F D I)_{i t}+\phi_{2}(M 2)_{i t}+\varepsilon_{i t}
$$

Where

$\alpha_{i}$ :- captures any country specific effects such as initial endowments .

$\gamma_{t}$ :- captures any common period specific effects such as general technical progress.

$\varepsilon_{i t}:-$ is an independent disturbance and the subscripts $i$ and $t$ represent country and time period, respectively

$G D P$ - Annual growth rate.

$C A P$ - the value of listed shares divided by GDP.

$S T V$-total value of shares traded on the stock market exchange divided by GDP.

$S T R$ - the value of total shares traded divided by market capitalization.

$M 2$ - Average annual growth rate in money.

FDI - The amount of foreign direct investment and portfolio inflows and outflows divided by GDP.
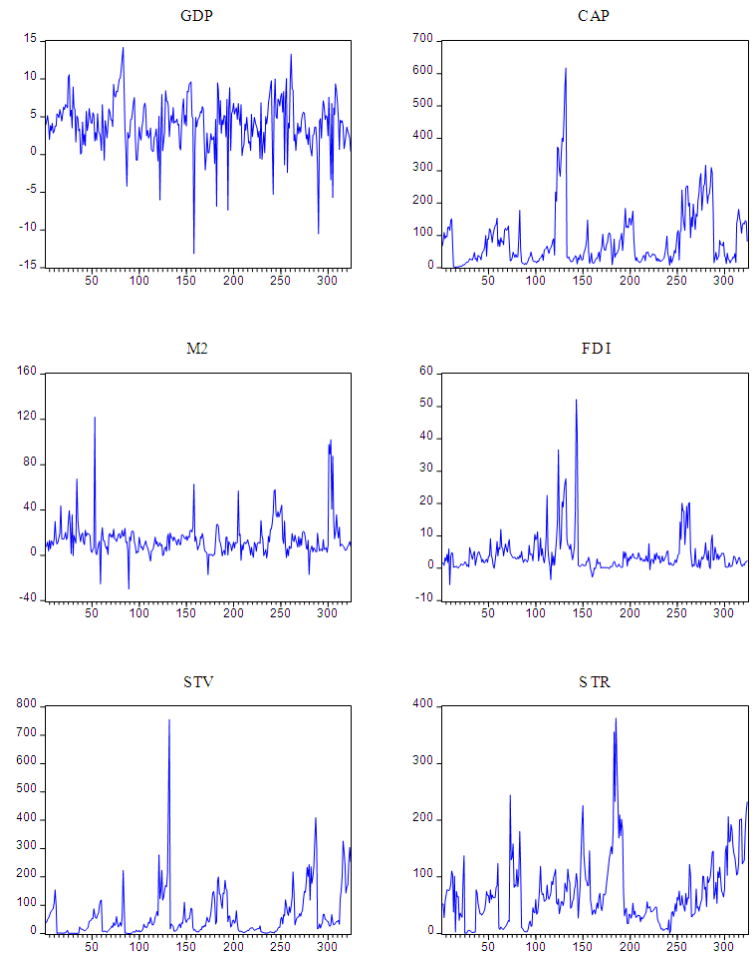

Figure 1. Value of the Stock market and economic variables.

\subsubsection{Data Sources}

Historical yearly data on CAP, STV, and STR data for twenty-seven emerging and developed market countries are obtained from the Emerging Markets Database (EMDB) provided by the International Financial Corporation (IFC) and the world development indicator data base provided by World Bank and International monetary fund (IMF). Growth, FDI, and M2 data's are from the World Development Indicators (2000) data set ${ }^{5}$.

\footnotetext{
${ }^{5}$ Construction of the EMDB began in 1981. To have a better understanding of
}

Emerging markets are countries that are restructuring their economies along market-oriented lines and offer a wealth of opportunities in trade, technology transfers, and foreign direct investment. According to the World Bank, the five biggest emerging markets are China, India, Indonesia, Brazil and Russia. Other countries that are also considered as emerging markets include Mexico, Argentina, South Africa, Thailand, and Turkey. These countries made a critical transition from a developing country to an emerging market. Each of them is important as an individual market and the combined effect of the group as a whole will change the face of global economics and politics.

Developed market countries are countries that have a high level of development according to some criteria. One such criterion is income per capita; countries with high gross domestic product (GDP) per capita would thus be described as developed countries. Another economic criterion is industrialization; countries in which the tertiary and quaternary sectors of industry dominate would thus be described as developed. More recently another measure, the Human Development Index (HDI), which combines an economic measure, national income, with other measures, indices for life expectancy and education has become prominent. This criterion would define developed countries as those with a very high (HDI) rating.

\subsection{Selection Criteria}

Countries were selected mainly by data availability, based on a requirement that each country have at least 10 years of continuous data and met some criteria such as high income economies ${ }^{6}$.

Developed countries and emerging market countries met the criteria under the following categories.

1 . They are high income economies (as measured by the World Bank GNI Per capita Rating, 2008)

2. Market and Regulatory Environment EMG

i. Formal stock market regulatory authorities actively monitor market.

ii. Fair and non-prejudicial treatment of minority shareholders.

iii. Non or selective incidence of foreign ownership restrictions.

iv. No objections or significant restrictions or penalties applied on the repatriation of capital.

v. Free and well-developed equity market.

vi. Free and well-developed foreign exchange market.

vii. Non or simple registration process for foreign investors.

3. Custody and Settlement

the data source and measurement criteria see Errunza and Losq (1985).

${ }^{6}$ As measured by the World Bank GNI Per capita Rating, 2008. 
i. Settlement - Rare incidence of failed trades

ii. Custody-Sufficient competition to ensure high quality custodian services

iii. Clearing \& settlement $-\mathrm{T}+3$ or shorter, $\mathrm{T}+7$ or shorter for Frontier

iv. Stock Lending is permitted

v. Settlement - Free delivery available

vi. Custody - Omnibus account facilities available to international investors

4. Dealing Landscape

i. Brokerage - Sufficient competition to ensure high quality broker services

ii. Liquidity - Sufficient broad market liquidity to support sizeable global investment

iii. Transaction costs - implicit and explicit costs to be reasonable and competitive

iv. Short sales permitted

v. Off-exchange transactions permitted

vi. Efficient trading mechanism

vii. Transparency - market depth information / visibility and timely trade reporting process

5. Derivatives and Size of the Market

i. Developed derivatives markets

ii. Market Capitalization

iii. Total Number of listed company

Table 1. Sample of Emerging Market and Developed Market Countries Used for our Study.

\begin{tabular}{llll}
\hline \multicolumn{1}{l}{ Emerging Market countries } & & \\
\hline Bangladesh & Columbia & Malaysia & Thailand \\
Botswana & Czech.rep & Mexico & Turkey \\
Brazil & Hungary & Peru & \\
Chile & India & Russia & \\
China & Indonesia & South Africa & \\
Developed Market & Countries & & \\
Australia & Hong Kong & Singapore & United states \\
Canada & Japan & South Korea & \\
Denmark & New Zealand & Switzerland & \\
\hline
\end{tabular}

\section{Panel Regression Results and Empirical Analysis}

To examine the relationship between stock market development and economic Growth, we employ the generalized-method-of moments (GMM) estimators developed for dynamic panel models by Arellano and Bond (1991) and Holtz-Eakin et al. (1988). As Edison et al. (2002) argue, the dynamic panel approach offers many advantages for researchers in the estimation of a relationship. First, dynamic panel econometric technique allows us to exploit the relationship between the variables with pooled crosssection. Second, by using this technique we are able to remove any bias created by unobserved country-specific effects. Third, it controls for the potential endogeneity of all explanatory variables. Thus, we view the dynamic panel estimator as a better technique to examine the relationship mentioned above.

As can be seen in Table two, we present the results of the GMM dynamic panel estimation. The development of Stock market has a positive significant effect on economic growth. And the Table also yields surprisingly consistent results, certainly with respect to the behavior of the three stock market variables, pointing to the robustness of these variables in the Present context. Table three shows the correlation among stock market variables and control variables. This shows as that they are not highly correlated. Table four presents summary statistics of for emerging market and developed market countries for 12 years average data.

The results in Table two are intuitive. One the one hand, well-functioning stock markets allow for greater and more efficient risk sharing, thereby making it possible for firms to undertake relatively riskier projects and, hence, promote growth. On the other hand, Stock markets widely distribute equilibrium prices that reflect demand and supply conditions, and knowledge of those prices allows investors, consumers, and producers to make informed decisions. Consequently, the amelioration of information and transaction costs fosters efficient resource allocation, thus leading to economic growth.

Moreover the results are also consistent with the argument put forward by Levine and Zervos (1998) and Rousseau and Wachtel (2000) that market liquidity is related to economic growth more significantly than market size. One might argue that the value traded ratio, which measures the value of shares traded as a ratio to national output, should be expected to have a significant relationship with economic growth. A country could have a relatively large stock market in terms of size, yet this might constitute a small proportion of its GDP. Increases in liquidity are important in emerging markets as they restore the confidence of investors in the value of information associated with trading (Rousseau and Wachtel (2000)). As investors are encouraged by high market liquidity to invest in equities, increasing the flow of venture capital, such moves would efficiently allocate resources and hence enhance economic growth in the long run. One of the important roles that a stock market plays is to re-channel the unused funds by financial intermediaries to productive and innovative investments.

The results also suggest that a stock market can effectively mobilize funds that have been not fully absorbed by financial intermediaries into productive investments and hence spur economic growth. And it also tells us that total value of shares traded ratio (STV) is not an effective measure of stock market liquidity. This may be especially so in emerging countries where stock markets are highly volatile, causing the value of shares traded to be misleading indicators of liquidity. 
Table 2. Panel Data Result.

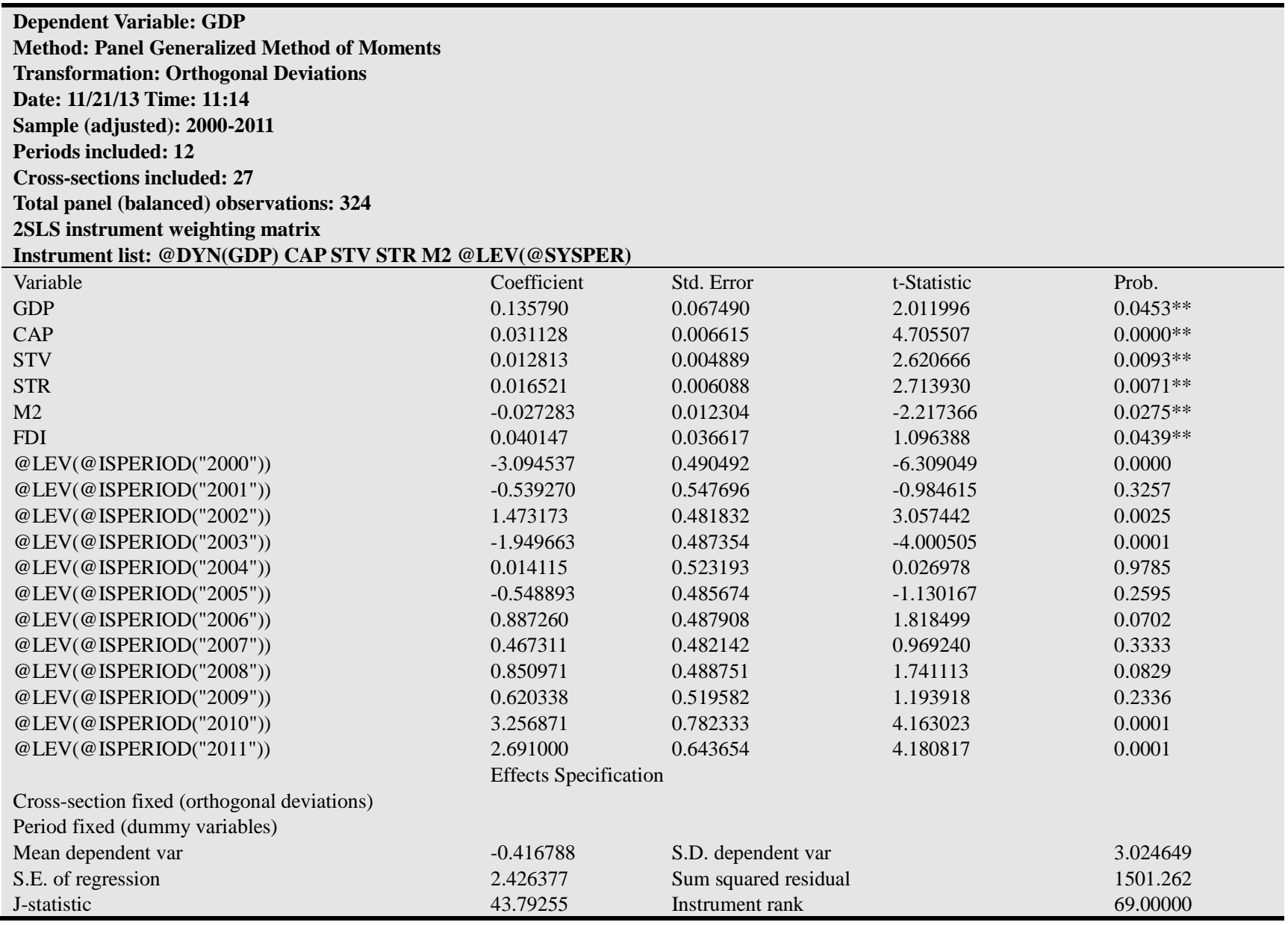

Note: index **, significant under 5\% Level.

One possible explanation for why stock Market development predicts the economy is that stock prices actually cause what happens to the economy. This would be consistent with the wealth effect. According to this argument, fluctuations in stock prices raise and lower wealth, which in turn, raises and lowers aggregate consumption.

Another interesting result is that CAP is significant stock market indicator in a direct test of stock market development on economic growth; one interpretation of this result given the earlier discussion and the evidence of model is that a stock market that is larger in size leads to higher investment opportunities, rendering market capitalization a better instrument to represent investments.
This model is in turn consistent with the hypothesis per Levine (1991) that liquidity (measured here by turnover ratio) has a direct influence on growth, besides the role played by market size.

Overall, both turnover ratio and market capitalization are important variables as determinants of economic growth. And the relationship between stock market development and economic growth are consistent with Levine and Zervos (1998) and Rousseau and Wachtel (2000). Which suggest that there is strong and statistically significant relationship between initial stock market development and subsequent economic growth.

Substituted coefficients of the model is shown as

$$
G D P=0.032(C A P)+0.013(S T V)+0.017(S T R)-0.028(M 2)+0.040(F D I)
$$

Table 3. Correlation of the Variables.

\begin{tabular}{lllllll}
\hline & GDP & CAP & M2 & FDI & STR & STV \\
\hline GDP & 1.00000 & 0.89295 & 0.56696 & 0.70092 & 0.73069 \\
CAP & 0.89295 & 1.00000 & -0.18174 & 0.89295 & 0.06272 \\
M2 & 0.56696 & -0.18174 & 1.00000 & -0.11986 & 0.04101 \\
FDI & 0.70092 & 0.89295 & -0.11986 & 1.00000 & -0.06622 \\
STR & 0.73069 & 0.06272 & 0.041018 & -0.06622 & -0.16414 \\
STV & 0.81806 & 0.76604 & -0.16414 & 0.27741 & 0.27741 & 0.00000 \\
\hline
\end{tabular}


Table 4. Descriptive Statistics of the Variables.

\begin{tabular}{llllll}
\hline Variable & observation & Mean & Std. Dev & Min & Max \\
\hline Year & 324 & 2005.5 & 3.457392 & 2000 & 2011 \\
GDP Growth & 324 & 4.145821 & 3.280635 & -6.537992 & 14.78079 \\
MCR & 324 & 89.71282 & 90.91067 & 2.435864 & 617.0462 \\
STR & 324 & 77.36967 & 60.29978 & 1.808225 & 380.3 \\
STV & 324 & 71.11818 & 95.91282 & .2935637 & 755.1004 \\
M2 & 324 & 26.35639 & 43.20393 & -29.82445 & 327.9526 \\
FDI & 324 & 4.126768 & 6.714405 & -19.2747 & 52.13266 \\
\hline
\end{tabular}

This table summarizes country-year statistics for 17 emerging and 10 developed market economies according to the World Bank 2008 GNI per capita. OECD and nonOECD countries classified according to the World Bank. The time series average of each variable is calculated and then statistics are collected a cross-country.

\section{Conclusion and Summary}

Our dynamic panel study results show that there exists a statistically significant positive relationship between stock market development and economic growth. Because the dynamic panel estimator controls for the potential endogeneity of all explanatory variables and unobserved country specific effects, our results are not due to such possible biases. Our panel study results are consistent with model that predict that well-functioning stock markets provide opportunities for firms to have more efficient and greater risk sharing along with amelioration of information and transaction costs, and thereby, promote economic growth. The results are also vigorous and robust that indicated stock market development is an important wheel for economic growth.

The empirical relationship between stock market development and economic growth remains strong even after controlling for Foreign Direct Investment, and money growth. Our findings suggest that stock market development contributes to economic growth both directly and indirectly. Following the direct channel, we show that market liquidity (turnover ratio) has a positive impact on growth. Indirectly, money growth affects market size (capitalization ratio) which, in turn, affects growth. The empirical results do support the theoretical literature (e.g., Levine, 1991), in suggesting that the stock market development leads to higher growth because it reduces both liquidity and productivity shocks.

In conclusion, the results revealed that the development of stock market does help predict the future economy. Although it may not be surprising to find that fluctuations in economic activity may be preceded by changes in stock market development. Our findings suggest that the evolution of financial sector in particular the stock market development tends to be more likely to stimulate and promote economic growth when monetary authorities adopt liberalized investment and openness policies, and improve the size and the regulations of the stock market development. This is consistent with the fact that the developed countries with well structured stock markets derive higher growth effects than the emerging market countries.

The need for further research is obvious in order to get more evidence about the impact of stock market development on economic growth or the vice versa. Although our study sheds light on the role of stock market development on economic growth, it does not study individual country cases, nor analyzes when countries are ready for stock markets development. (For information on specific country experiences with stock market development, see El-Erian and Kumar (1995); and Classens (1995).

The first need for future empirical research is more data. With only Twelve years worth of data, the panel estimation techniques used in this paper are barely adequate. Twenty years worth would be ideal as that would allow the time series elements to be more robust. With more years of data, the Nickell bias issue would be further suppressed. Also, more sophisticated analysis of time lags would be possible.

In general, there is a need for more efficient estimators. There are estimators like the Feasible Generalized Spatial Three Stage Least Squares (FGS3SLS) estimator that would be more efficient, but, as of this writing, such an estimator would require considerable computer programming in a language like Matlab as it is not implemented as a fully supported feature in any econometric software. A good estimator would be one that combines dynamics, simultaneous equations and spatial effects all into one. There is active research on this question but, so far, a workable estimator has not been forthcoming.

Finally, to better understand the relationship between stock market development and economic growth, one may need to adopt more complex vector autoregressive (VAR) models that have been developed for panel data ${ }^{7}$.

\section{Acknowledgment}

This work was supported by National Natural Science

${ }^{7}$ For a detailed study of VAR with Panel see Holtz-Eakin, Newey, and Rosen (1989). 
Foundation of China (NO. 71171031, 70471055, 79770011), Science and Technology Research Project of Ministry of Education of China (NO. 2011-10). Credit Risks Rating System and Loan Pricing Project of Small Enterprises for Bank of Dalian (2012-01).

\section{References}

[1] Adajaski, Charles K.D. and Nicholas, B.Biekpe (2005) Stock Market Development and Economic Growth. The Case of Selected African Countries Working Paper, African Development Bank, 98, 117-201.

[2] Arellano, M., and S. Bond, (1991) Some Tests of Specification for Panel Data: Monte Carlo Evidence and an Application to Employment Equations, Review of Economic Studies, 58, 277-297.

[3] Arellano, M. and O. Bover. 1995. "Another look at the instrumental variable estimation of error-components models." Journal of Econometrics, 68, 29-51.

[4] Arestis, Philip, Demetriades, Panicos, O. and Luintel, Kul B. (2001), Financial Development and Economic Growth: The Role of Stock Markets, Journal of Money, Credit and Banking, 33, 16-41.

[5] Atje, R., and B. Jovanovic, (1993) Stock Markets and Development. European Economic Review, Vol. 37, 632-64.

[6] Bagehot, (1873), A Description of Money Market with Currency Monopoly, Homewood. ILRichard, 1962.

[7] Bahadur and Neupane, (2006), "Stock Market and Economic Development: a Causality Test, The Journal of Nepalese Business Studies, pp: 36-44.

[8] Beck, T. and Levine, R. (2004) Stock markets, banks and growth panel evidence. Journal of Banking and Finance, 38, 423-442.

[9] Bekaert, G., Harvey, C. and Lundblad, C. (2001) Emerging equity markets and economic development, Journal of Development Economics,66, 465-504.

[10] Benchivenga, V. R. and Smith, B. D, (1991) Financial Intermediation and Endogenous Growth. The Review of Economic studies, Vol. 58, pp. 195-209.

[11] Blundell, R., and S. Bond, (1998), Initial Conditions and Moment Restrictions in Dynamic Panel Data Models, Journal of Econometrics, 87: 115-143.

[12] Caporale, Howells and Soliman, (2004), Stock Market Development and Economic Growth: A Casual Linkage, Journal of Economic Development, 29, PP:33-50.

[13] Chen, Lee and Wong, (2004), Is Rate of Stock Returns a Leading Indicator of Output Growth? In Case of Four East Asian Countries. American Economic Review, 71, 545-564.

[14] Christopoulos, D. and Tsionas, E. (2004), Financial development and economic growth: evidence from panel unit root and co-integration tests, Journal of Development Economics, 73, 55-74.

[15] Comincioli, Brad (1996), "The Stock Market as a Leading Indicator: An Application of Granger Causality, The University Avenue Undergraduate Journal of Economics,
Sample Issue.

[16] Deidda, L. and Fattouh, B. (2002) Non-linearity between finance and growth, Economics Letters, 74, 339-45.

[17] Demetriades, P. and Hussein, K. (1996) Does financial development cause economic growth? Time-series evidence from 16 countries, Journal of Development Economics, 51, $387-411$.

[18] Demirguc-Kunt, A. (1994)Developing Country Capital Structure and Emerging Stock Markets, Policy Research Working Paper, WPS 933, July.

[19] Edison, H., Levine, R., Ricci, L. and Slok, T. (2002) International financial integration and economic growth, Journal of International Money and Finance, 21, 749-76.

[20] Filer, Hanousek and Nauro, (1999), Do Stock Markets Promote Economic Growth? Working Paper No.267.

[21] Graff, M. (2002) Causal links between financial activity and economic growth: empirical evidence from a cross country analysis, (1970-1990), Bulletin of Economic Research, 54, 119-33.

[22] Greenwood, J., Jovanovich, B. (1990) Financial Development, Growth and the Distribution of Income Journal of Political Economy, Vol.98, pp.1076 - 1104.

[23] Holtz-Eakin, D., Newey, W., and H. Rosen. (1989). "Estimating Vector Auto regression with Panel Data." Econometrica, Vol. 56, 1371-1395.

[24] International Finance Corporation (1998). Emerging Stock Markets CD-ROM. (IFC Washington D.C.)

[25] Islam, N. (1995). Growth Empirics: A Panel Data Approach. Quarterly Journal of Economics, Vol. 110: 1127-1170.

[26] Kassimatis, K. and Spyrou, S. (2001) Stock and credit market expansion and economic development in emerging markets: further evidence utilizing co integration analysis, Applied Economics, 33, 1057-64.

[27] Levine, R., and S.J. Zervos (1995) Stock Market Development and Long-Run Growth. World Bank Economic Review, Vol. 82, No. 4, 942-963.

[28] Levine, R., Zervos , S, (1996) Stock Market Development and Long Run Growth, The World Bank Economic Review, Vol 10(2), pp.323-339.

[29] Levine, Ross and Sarah Zervos, (1998) Stock Markets, Banks, and Economic Growth, American Economic Review $88: 537-558$

[30] Luintel, K., \& Khan M. (1999). A quantitative reassessment of the finance-growth Nexus: Evidence from a Multivariate VAR. Journal of Development Economics, 60, 381-405.

[31] Mauro, P. (2003), Stock returns and output growth in emerging and advanced economies, Journal of Development Economics, 71, 129-53.

[32] Minier, J. (2003) Are small stock markets different? Journal of Monetary Economics, 50, 1593-602.

[33] Mirakhor, and R.M. Lillanueva, (1990), Market Integration and Investment Barriers in Emerging Equity Markets, World Bank Discussion Paper, No. 216, 221-255. 
[34] Mishkin, Frederic S, (2001) The Economics of Money, Banking, and Financial Markets, 6thed. New York: Addison Wesley Longman.

[35] Obstfeld, (1994), Risk-Taking, Global Diversification, and Growth, American Economic Review, 84 pp. 1310-1329. Papers financial policy and systems. No, 907, World Bank.

[36] Pardy, R, (1992), Institutional Reform in Emerging Securities Markets, Policy Research Working paper

[37] Paudel, N. P. (2005), Financial system and economic development. Nepal Rastra Bankin Fifty Years, Part II,Financial System. Kathmandu: NRB.

[38] Rajan, R.G., and Zingales, L. (1998) Financial Dependence and Growth. American Economic Review 88, 559-586.

[39] Robinson, J. (1952) The Rate of Interest and Other Essays. London: MacMillan. Chapter the generalization of the general theory. pp. 34 .

[40] Rousseau, Peter and Wachtel, Paul (2000), Equity Markets and Growth: Cross Country Evidence on Timing and Outcomes, 1980- 1995, Journal of Banking and Finance, 24: 1933- 1957.

[41] Schumpeter, J.A., 1911. The Theory of Economic Development. Harvard University Press, Cambridge, MA.

[42] Spears, Annie, (1991) Financial Development and Economic Growth-Causality Tests, Atlantic Economic Journal, 19:6674.

[43] Stiglitz, J.E., and A. Weiss, (1981), Credit Rationing in Markets With Imperfect Information, American Economic Review, Vol. 71, 393-410.

[44] World Development Indicators (2000) CD-ROM the World Bank, Washington D.C. 